Journal of Health, Medicine and Nursing

ISSN 2520-4025 (Online)

Vol.6, Issue 3. No.4, pp 49- 65, 2021

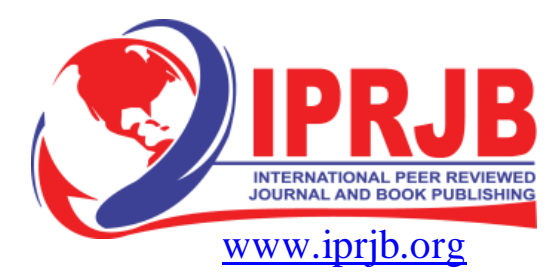

\title{
Video versus Traditional Teaching Strategy for Enhancing Intramuscular Injection Skills among College of Nursing Students in Kuwait: A Comparative Study

\author{
$1^{*}$ Dr Abeer William
}

1Assistant Professor of Medical Surgical Nursing, on tenured leave from College of Nursing, Ain-Shams University. Assistant Professor of Medical Surgical Nursing, College of Nursing, Kuwait.

*Corresponding Author: aw.aziz@paaet.edu.kw

2 Mrs. Victoria L. Vidal

2 Lecturer of Medical Surgical Nursing, College of Nursing, Kuwait

3 Dr. Helalia Shalabi Mohamed

3Assistant Professor of Community Health Nursing, College of Nursing, Cairo University, Assistant Professor of Community Health Nursing, College of Nursing, Kuwait

\begin{abstract}
Purpose: The study aims to assess the performance and compare the effectiveness of intramuscular injection skills of nursing students utilizing two different teaching strategies -traditional (with the use of performance checklist only) versus video (together with the performance checklist).

Methodology: A quasi-experimental research design was used. The sample was divided into two groups - control group, 28 female nursing students and experimental group, 27 male nursing students. Socio-demographic data sheet and an observational checklist were used to collect pertinent data.. Analysis was performed using descriptive statistics and analytical tests, such as the independent t-test between the experimental and control group, regarding the preparation and injection of medication. P value of $<0.05$ was considered to be significant.

Findings: Most of the experimental and control group subjects are non-Kuwaitis. In medication preparation, the experimental group showed higher scores in the following steps: mixing solution; withdrawing prescribed amount of medication. The control group, on the other hand, scored higher in the following steps: removing needle cap, withdrawing into syringe amount of air equal to volume of medication to be withdrawn; carefully inserting needle into upright vial; and withdrawing prescribed amount of medication. In medication administration, the control group obtained higher scores in putting on clean gloves and applying gentle pressure at the site. The experimental group had higher score only in putting on clean gloves. A highly significant positive correlation was found between medication preparation and injection of medication and sociodemographic parameters of age and nationality $(\mathrm{p}=0.008, \mathrm{p}=0.007)$ respectively. There is no statistically significant correlation detected between control and experimental group in relation to injection of the medication.
\end{abstract}

Unique Contribution to Theory and Practice: The results of this study indicated that while traditional and video-assisted teaching are equally effective, there is no substitute for clinical demonstration.

Key Words: Nursing students; Video; Traditional Teaching Strategy; Intramuscula 
Journal of Health, Medicine and Nursing

ISSN 2520-4025 (Online)

Vol.6, Issue 3. No.4, pp 49- 65, 2021

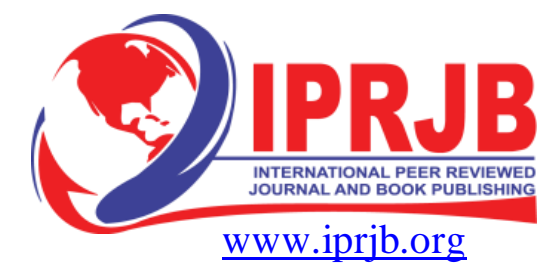

\section{INTRODUCTION}

One of the most common health care procedures globally is the giving of injections (WHO, 2014). In developing countries, approximately 16 million injections are administered every year (Rathod et al., 2013), with more than 90\% given for therapeutic purposes, and 5-10\% for preventive purposes (Shill et al., 2011). Nurses often use intramuscular (IM) injections as a medicine delivery method (Gulnar and Ozveren, 2016; Topal and Yildirim, 2014). While administering IM injection is perceived as a simple skill, there are a complex series of considerations such as the type and volume of injectate, medication to be given, technique, site selection and equipment (Sakic et al., 2012).

The use of IM injection is associated with complications, discomfort and painful experience of many patients (Agac and Gunes, 2011). IM injections not administered carefully may lead to "pain, abscesses, necrosis, infection, hematoma, periostitis, as well as vascular or bone injury" (Potter and Perry, 2009). Out of 12 billion injections administered worldwide annually, World Health Organization has estimated that 50\% are unsafe, and 75\% are unnecessary (Deena and Nashwan, 2014). Globally, unsafe injection practices result in millions of infections leading to serious morbidity and mortality, particularly blood borne transmission of hepatitis B and C and human immunodeficiency virus (RuLiou and Yu Cheng, 2014).

Competence of health care practitioners to include the nursing students plays a highly significant role in the safety of patients (Ghamari Zare et al., 2013). Safe and proper IM injection technique is vital for health care providers; hence, it is significant that nursing students be trained properly in this procedure before they are involved in clinical practice (Srividya et al., 2015). It is essential that each health care institution has the best clinical practice guidelines for IM injections. Nurse educators have the challenge and the responsibility to promote nursing students' competence prior to graduation (El-Demerdash et al., 2015).

The role of nurses in the process of medication is critical. Through evaluation of the process, the present status would be determined by the nurse educators and students, and eventually could lead to improving the quality of care (Ghamari Zare et al., 2013). 
Journal of Health, Medicine and Nursing

ISSN 2520-4025 (Online)

Vol.6, Issue 3. No.4, pp 49- 65, 2021

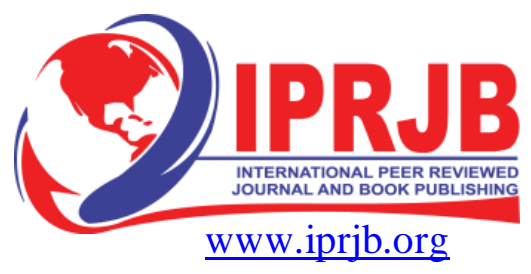

Accuracy and proficiency are essential in performing nursing procedures; hence, nurse educators play a vital role in teaching, training, and evaluating students (Alawadi, 2017). In the study of Sakic et al. (2012), the respondents carried out IM administration procedures traditionally. This confirms the necessity for written instructions for implementing the procedure to carry it out uniformly and to prevent adverse effects (Sakic et al., 2012). In educational settings, wellconstructed checklists codify interventions, remove ambiguity, and increase the reliability of care processes (Rosen and Pronovost, 2014). Aside from serving as evaluation tools, checklists facilitate communicating a set of expectations regarding effective performance. Observational checklists help educators identify areas of teaching and learning to provide significant insights and achieve proficiency (Alawadi, 2017). Evidence-based practices have been translated to the bedside for a wide range of complications through the use of checklists (Rosen and Pronovost, 2014)

Today's nursing students are provided with an easy, innovative, and user-friendly way to learn which can be adapted into nursing courses at any level with the use of video (Devi, 2019). Increasingly, these students enter the nursing programs knowledgeable about different media offerings and communication technologies. It is therefore expected that nurse educators should enrich the learning environment with the use of creative communication technologies. Videos support and stimulate student comprehension in several contexts: in the classroom, in the laboratory and in distance education (Agazio J, 2009; Keelan J et al., 2007). Educators realize the value of combining auditory and visual enhancement within the traditional lecture (Salina et al., 2012)

Video as a valid tool for student education has been well documented (Bennet M and Maniar M, 2008). Among the key elements of video streaming are its pedagogical aspects, the impact of the image, the interaction and integration (Thornhill S et al., 2002). In the literature, a variety of studies has confirmed that video streaming is a powerful instrument for education and for the acquisition of clinical competencies; hence, decreasing the gap between theory and practice (Forbes MO and Hickey MT, 2008; Baharav E, 2008). Observational studies have demonstrated that video streaming 
Journal of Health, Medicine and Nursing

ISSN 2520-4025 (Online)

Vol.6, Issue 3. No.4, pp 49- 65, 2021

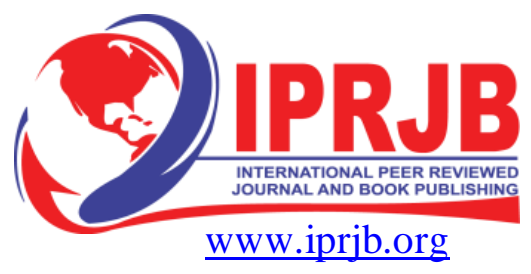

has been positive in terms of effectiveness and facilitation of learning (Takeda $\mathrm{N}$ et al., 2007). Some authors suggest how the video can facilitate student learning of different types of techniques (Baharav, 2008). Video use is an experiential process and should enhance learning processes in the same manner as experience is acquired during practical training.

There are few experimental studies which demonstrate the effectiveness of video applied to traditional nursing techniques (Kluge, MA and Glick L, 2006; Bauer et el., 2001). In a randomized controlled trial (RCT), conducted by medical students, results showed that a three-minute video play yielded a comparable or better performance than that used in the American Heart Association (AHA) course (Todd KH et al., 1998). In an experimental study measuring qualitative variables, Cofield (2012) suggested the effectiveness of video to reinforce learning. Videos add value to learning content and are certainly among the most interesting technologies (Salina et al., 2012). The detailed image offers students the possibility of using more channels, thereby facilitating and enhancing learning processes.

The delivery of education in tertiary institutions is strongly influenced by communications technology. The research review of Forbes et al. (2016) revealed that while the increased use of videos support the teaching and learning of clinical skills in nursing, there is a need to document this area of inquiry. Evidence on the efficacy of videos to support student learning is still wanting. The aim therefore of this study is to verify the effectiveness of video as an instrument in reinforcing the teaching of the intramuscular injection.

\section{Problem Statement}

What teaching strategy - the video or the traditional, would result to a more effective intramuscular skill among the nursing students in the College of Nursing, Kuwait?

Enhancing the skill proficiency of nursing students is a continuing combined concern of the teachers and the students. A study on strategies for improving nursing student skills would therefore be of value to the providers of education, the teachers, and the recipients of education, the nursing students. 
Journal of Health, Medicine and Nursing

ISSN 2520-4025 (Online)

Vol.6, Issue 3. No.4, pp 49- 65, 2021

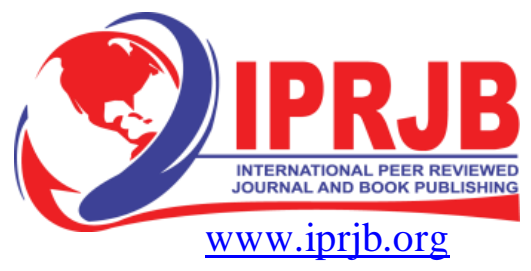

\section{Significance of the Study}

Findings of this research could lead to overall improvement of the intramuscular skill proficiency of the nursing students. Particularly, the results could pave the way for modifying the teaching strategies in the laboratory sessions to be more responsive to the learning needs of the students. Improved performance of skills among nursing students would strongly enhance their confidence and delivery of care to patients in different health care settings including community health care facilities. High level of competency in clinical skills acquisition may reduce healthcare costs, patient morbidity, and mortality rates and increase patient safety (Hibbert et al., 2013; Holland et al., 2013).

\section{PURPOSES OF THE STUDY}

Aims of the study are to:

1. Assess the performance of intramuscular injection skills of students utilizing two different teaching strategies:

a. Traditional, using a performance checklist only;

b. Use of video and a performance checklist;

2. Compare the effectiveness of the above teaching strategies as shown in the performance of intramuscular injection skills of students.

\section{METHODOLOGY}

\section{Design}

A quasi-experimental research design was utilized for the study. A control group and experimental group were used to examine the effectiveness of the video as a teaching strategy for enhancing intramuscular injection skills of the nursing students in comparison with the traditional method of teaching. 
Journal of Health, Medicine and Nursing

ISSN 2520-4025 (Online)

Vol.6, Issue 3. No.4, pp 49- 65, 2021

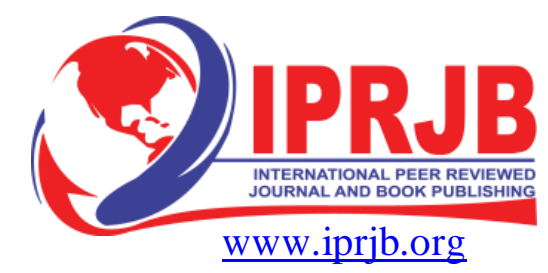

\section{Setting/Target Population}

This study was conducted in the College of Nursing, Kuwait which has the distinction of being the only educational facility in the country which offers an Associate of Nursing (ADN) and Bachelor of Science in Nursing (BSN) degrees. The ADN program consists of five academic semesters and admits both female and male students, who represent different nationalities Kuwaitis, Arabs and Gulf Cooperative Council. A majority, 80\%, of the College population comes from this program.

\section{Sample}

A convenience sample which included all the 55 second level students in the Associate Degree Program enrolled in medical surgical nursing, first semester of 2017-2018 was used. The sample was divided into two groups: (1) the control group, consisting of 28 female students and (2) the experimental group, consisting of 27 male students. The focus was on level 2 since the procedure on intramuscular injections which is being experimented on is taught during this period. Excluded from the study were the BSN students who represented only $20 \%$ of the College enrollment.

\section{Tools}

Two main tools were used for the study. The first tool was on the student's socio-demographic data (age and nationality). The second tool used an observational checklist, which is divided into two parts: (1) Preparing medication from vial, 7 steps and (2) Administering Intramuscular injection, 9 steps. The preparation of medication from the vial consisted of the following steps: (1) Mix solution, if necessary, by rotating the vial between palms of hands, not by shaking; (2) Remove protective cap, or clean rubber cap with an antiseptic wipe in circular motion; (3) Remove needle cap, withdraw into syringe amount of air equal to volume of medication to be withdrawn; (4) Carefully insert needle into upright vial through center of rubber cap, maintaining sterility of needle; (5) Inject air into vial, keeping bevel of needle above surface of medication; (6) Withdraw prescribed amount of medication: Hold vial down, move needle tip below fluid level and withdraw medication; invert vial; ensure needle tip is below fluid level; and gradually withdraw medication; hold syringe and vial at eye level to determine correct dosage of drug is drawn into syringe; (7) 
Journal of Health, Medicine and Nursing

ISSN 2520-4025 (Online)

Vol.6, Issue 3. No.4, pp 49- 65, 2021

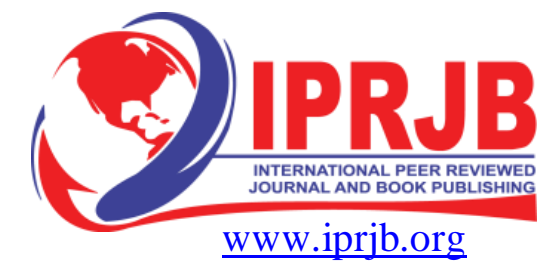

When correct volume of medication is obtained, withdraw needle from vial, and cover needle using the scoop method.

The steps included in administering the intramuscular injected were as follows: (1) Put patient in the right position; Locate the exact site for injection; (2) Put on clean gloves; (3) Clean site with antiseptic swab using a circular motion; (4) Remove needle cap, inject medication using Z-Track technique; (5) Hold barrel of syringe steady with non-dominant hand and aspirate for 5 to 10 seconds; (6) If blood does not appear, inject the medication steadily and slowly (about 10 seconds per milliliter; (7) Withdraw the needle smoothly at the same angle of insertion; (8) Apply gentle pressure at the site. Do not massage site; (9) Remove gloves, wash hands; Observe aseptic technique. Different scoring points were given to each checklist step depending on its importance. The content was reviewed by experts in the College faculty.

\section{Pilot Study}

The questionnaire was given to a group of four (4) students with the view of making modifications on the questions prior to the main research study. For the skill checklist to be utilized by the mentors in the Objective Structured Clinical Exam (OSCE), a session was priorly conducted with them to obtain their comments and suggestions.

\section{Data Collection}

Data were obtained from 28 female and 27 male level 2 students of the Associate Degree of Nursing Program at the College of Nursing enrolled during the first semester of 2017-2018. The questionnaires were administered in the classroom setting under the investigator's supervision. The observational skill checklist was accomplished during the Objective Structured Clinical Examination (OSCE) of the students. The raters of the two groups are familiar with the skill checklists, having been consistently rating the students for the past five years at least. Inter-rater differences are thereby reduced. 
Journal of Health, Medicine and Nursing

ISSN 2520-4025 (Online)

Vol.6, Issue 3. No.4, pp 49- 65, 2021

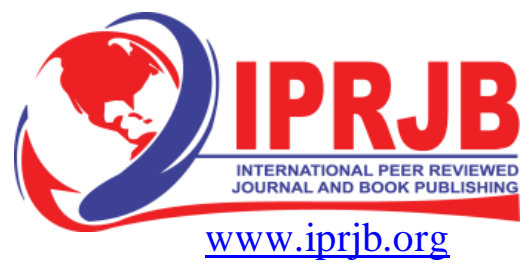

\section{Ethical Consideration}

Permission to conduct the study was sought from the cognizant authorities in the College of Nursing. The participants were informed about the nature of the study and the utilization of the results for the evaluation of the selected educational strategy - the use of video. The participant's signature on the consent signified willingness to participate. Anonymity and confidentiality were safeguarded throughout the study.

\section{RESULTS}

\section{Demographic Data}

The sample consisted of two groups with 28 students comprising the control group and 27 students composing the experimental group. For the control group, the age ranged from 18 to 40 ( $\mathrm{M}=$ $1.7857, \mathrm{SD}=.56811)$. On the other hand, for the experimental group, the age ranged from 18 to $30(\mathrm{M}=1.8148, \mathrm{SD}=.39585)$. Nationality for the control group was Kuwaitis $(14.3 \%)$ and other nationalities $(85.7 \%)$ while the experimental group had no Kuwaitis and $100 \%$ were nonKuwaitis.

\section{Comparative Findings between the Control and Experimental Group}

The control and experimental groups in the study met all the items in the checklist which would mean successful performance of the procedure. There are however, differences in results in terms of the performance. Table 1 gives us a glimpse into the descriptive statistics regarding the preparation of medication of the two groups 
Journal of Health, Medicine and Nursing

ISSN 2520-4025 (Online)

Vol.6, Issue 3. No.4, pp 49- 65, 2021

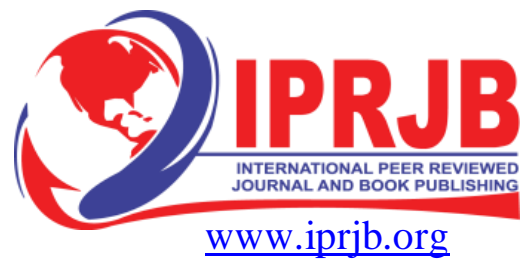

Table 1: Descriptive Statistics for Experimental and Control Groups regarding

\begin{tabular}{|c|c|c|c|c|c|}
\hline $\begin{array}{l}\text { Preparation } \\
\text { Procedure }\end{array}$ & Gender & $\mathrm{N}$ & Mean & $\mid \begin{array}{l}\text { Standard } \\
\text { Deviation }\end{array}$ & $\begin{array}{l}\text { Std } \\
\text { Mean } \\
\text { Error }\end{array}$ \\
\hline Pre.1 & male & $\begin{array}{l}27 \\
28\end{array}$ & $\begin{array}{l}2.0000 \\
1.8929\end{array}$ & $\begin{array}{l}.00000 \\
.31497\end{array}$ & $\begin{array}{l}.00000 \\
.05952\end{array}$ \\
\hline Pre. 2 & male & $\begin{array}{l}27 \\
28\end{array}$ & $\begin{array}{l}1.8889 \\
1.5714\end{array}$ & $\begin{array}{l}.32026 \\
.50395\end{array}$ & $\begin{array}{l}.06163 \\
.09524\end{array}$ \\
\hline Pre.3 & male & $\begin{array}{l}27 \\
28\end{array}$ & $\begin{array}{l}1.7778 \\
1.9286\end{array}$ & $\begin{array}{l}.42366 \\
.26227\end{array}$ & $\begin{array}{l}.08153 \\
.04956\end{array}$ \\
\hline Pre.4 & male & $\begin{array}{l}27 \\
28\end{array}$ & $\begin{array}{l}1.8148 \\
1.9643\end{array}$ & $\begin{array}{l}.39585 \\
.18898\end{array}$ & $\begin{array}{l}.07618 \\
.03571\end{array}$ \\
\hline Pre.5 & $\begin{array}{l}\text { male } \\
\text { female }\end{array}$ & $\begin{array}{l}27 \\
28\end{array}$ & $\begin{array}{l}1.7778 \\
1.8571\end{array}$ & $\begin{array}{l}.42366 \\
.35635\end{array}$ & $\begin{array}{l}.08153 \\
.06734\end{array}$ \\
\hline Pre.6 & male & $\begin{array}{l}27 \\
28\end{array}$ & $\begin{array}{l}1.9259 \\
2.0000\end{array}$ & $\begin{array}{l}.26688 \\
.00000\end{array}$ & $\begin{array}{l}.05136 \\
.00000\end{array}$ \\
\hline Pre.7 & male & $\begin{array}{l}27 \\
28\end{array}$ & $\begin{array}{l}1.8519 \\
1.7143\end{array}$ & $\begin{array}{l}.36201 \\
.46004\end{array}$ & $\begin{array}{l}.06967 \\
.08694\end{array}$ \\
\hline Tot.1 & male & $\begin{array}{l}27 \\
28\end{array}$ & $\begin{array}{l}4.6296 \\
4.7857\end{array}$ & $\begin{array}{l}.74152 \\
.62994\end{array}$ & $\begin{array}{l}.14271 \\
.11905\end{array}$ \\
\hline
\end{tabular}

As can be gleaned from Table 1, the means for the experimental group as far as the preparation of the medication are slightly higher in steps 1 (Mix solution, if necessary, by rotating the vial between palms of hands, not by shaking), 2 (Remove protective cap, or clean rubber cap with an 
Journal of Health, Medicine and Nursing

ISSN 2520-4025 (Online)

Vol.6, Issue 3. No.4, pp 49- 65, 2021

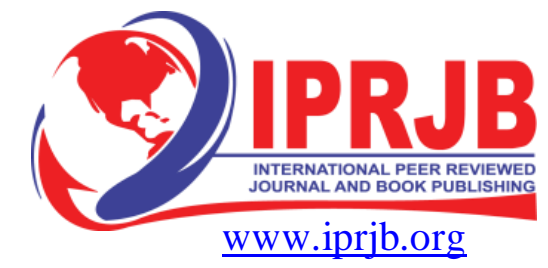

antiseptic wipe in circular motion), and 7 (When correct volume of medication is obtained, withdraw needle from vial, and cover needle using the scoop method). On the other hand, the control group has higher means in steps 3 (Remove needle cap, withdraw into syringe amount of air equal to volume of medication to be withdrawn), 4 (Carefully insert needle into upright vial through center of rubber cap, maintaining sterility of needle), 5 (Inject air into vial, keeping bevel of needle above surface of medication), and 6 (Withdraw prescribed amount of medication: Hold vial down, move needle tip below fluid level and withdraw medication. Invert vial; ensure needle tip is below fluid level; and gradually withdraw medication. Hold syringe and vial at eye level to determine correct dosage of drug is drawn into syringe). The overall means for the control group is higher. 
Journal of Health, Medicine and Nursing

ISSN 2520-4025 (Online)

Vol.6, Issue 3. No.4, pp 49- 65, 2021

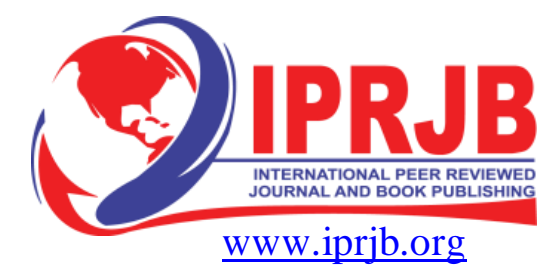

Table 2: Descriptive Statistics for Experimental and Control Group regarding Injection of Medication

\begin{tabular}{|c|c|c|c|c|c|}
\hline Injection procedure & Gender & $\mathrm{N}$ & Mean & Std. Deviation & Std. Error Mean \\
\hline \multirow[t]{2}{*}{ inj.1 } & male & 27 & 1.7037 & .46532 & .08955 \\
\hline & female & 28 & 1.7500 & .44096 & .08333 \\
\hline \multirow[t]{2}{*}{ inj. 2} & male & 27 & 1.8148 & .39585 & .07618 \\
\hline & female & 28 & 1.8214 & .39002 & .07371 \\
\hline \multirow[t]{2}{*}{ inj.3 } & male & 27 & 1.5556 & .50637 & .09745 \\
\hline & female & 28 & 1.6786 & .47559 & .08988 \\
\hline \multirow[t]{2}{*}{ inj.4 } & male & 27 & 1.4074 & .50071 & .09636 \\
\hline & female & 28 & 1.6071 & .49735 & .09399 \\
\hline \multirow[t]{2}{*}{ inj.5 } & male & 27 & 1.4074 & .50071 & .09636 \\
\hline & female & 28 & 1.5715 & .50402 & .09525 \\
\hline \multirow[t]{2}{*}{ inj.6 } & male & 27 & 1.7407 & .44658 & .08594 \\
\hline & female & 28 & 1.7143 & .46004 & .08694 \\
\hline \multirow[t]{2}{*}{ inj.7 } & male & 27 & 1.7407 & .44658 & .08594 \\
\hline & female & 28 & 1.7857 & .41786 & .07897 \\
\hline \multirow[t]{2}{*}{ inj. 8} & male & 27 & 1.7407 & .44658 & .08594 \\
\hline & female & 28 & 1.9286 & .26227 & .04956 \\
\hline \multirow[t]{2}{*}{ inj.9 } & male & 27 & 1.7407 & .44658 & .08594 \\
\hline & female & 28 & 1.6786 & .47559 & .08988 \\
\hline \multirow[t]{2}{*}{ tot. 2} & male & 27 & 3.7037 & 1.75005 & .33680 \\
\hline & female & 28 & 4.3571 & 1.12922 & .21340 \\
\hline \multirow[t]{2}{*}{ total3 } & male & 27 & 8.4074 & 1.88637 & .36303 \\
\hline & female & 28 & 8.8214 & 1.38921 & .26254 \\
\hline
\end{tabular}


Journal of Health, Medicine and Nursing

ISSN 2520-4025 (Online)

Vol.6, Issue 3. No.4, pp 49- 65, 2021

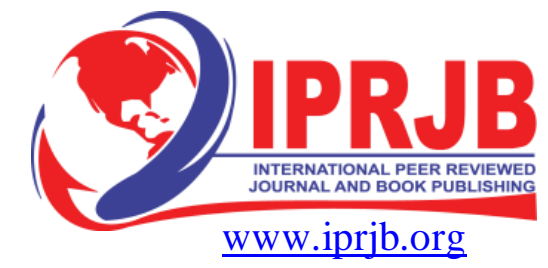

Table 2 reveals the means for the two groups in relation to the injection of the medication. The control group has higher means in all steps except for step 6 (If blood does not appear, inject the medication steadily and slowly, about 10 seconds per milliliter) and therefore, has higher overall means.

Tables 3A and 3B show the results of t-tests between the experimental and control groups regarding the preparation and injection of medication 
Journal of Health, Medicine and Nursing

ISSN 2520-4025 (Online)

Vol.6, Issue 3. No.4, pp 49- 65, 2021

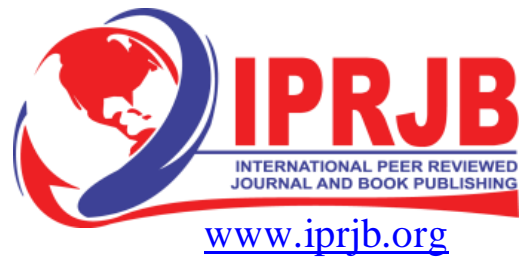

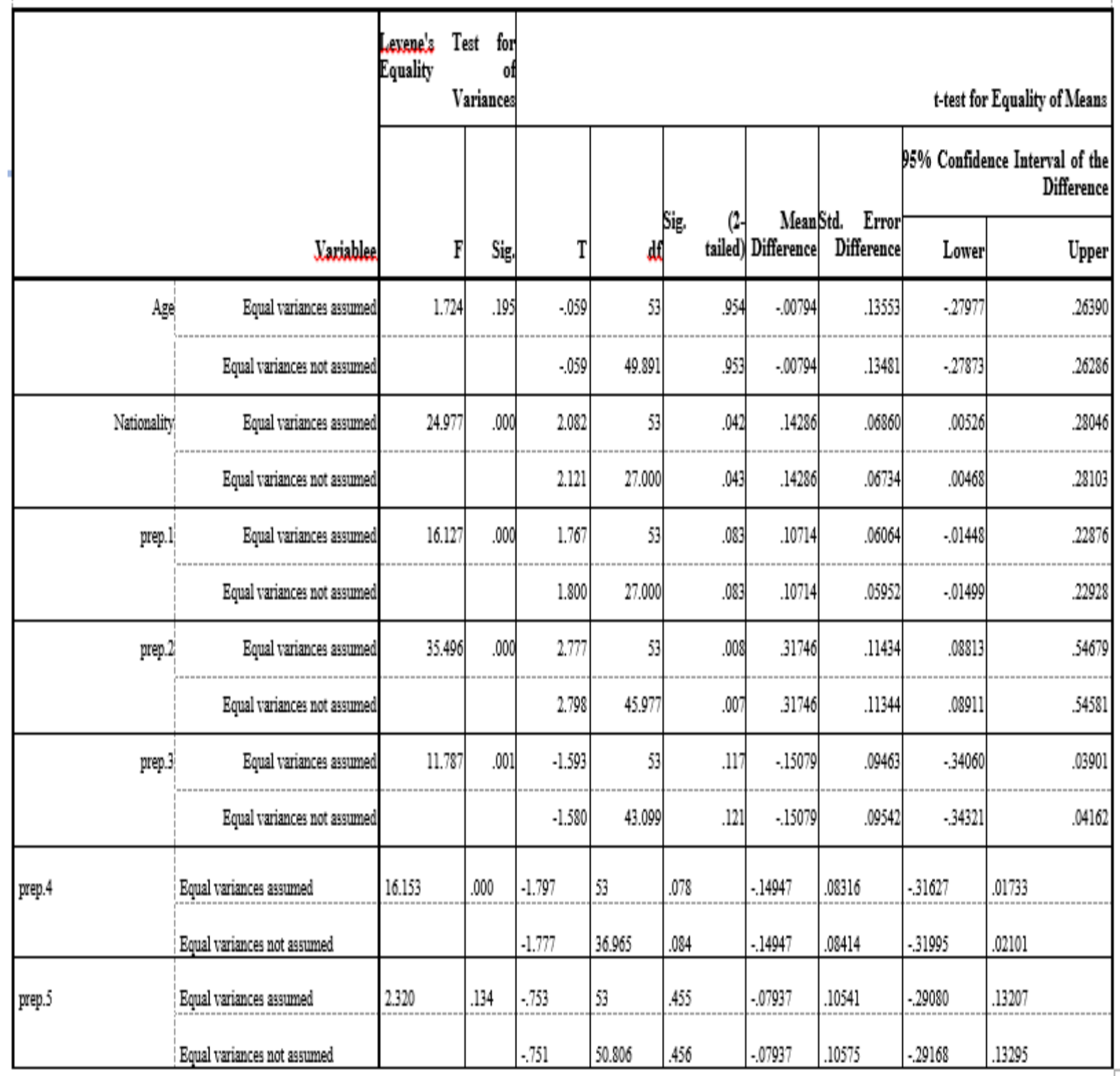


Journal of Health, Medicine and Nursing

ISSN 2520-4025 (Online)

Vol.6, Issue 3. No.4, pp 49- 65, 2021

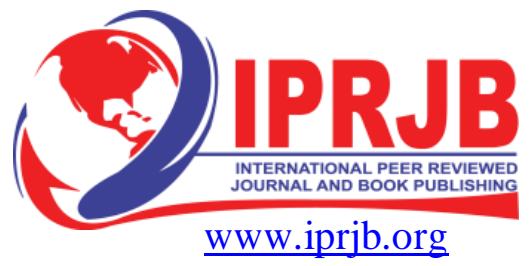

Table 3 B: Independent $T$ test- between Experimental and Control Groups regarding Preparation of Medication

\begin{tabular}{|c|c|c|c|c|c|c|c|c|c|c|}
\hline \multirow{3}{*}{ Variables } & & \multicolumn{2}{|c|}{$\begin{array}{l}\text { Lexene's Test for } \\
\text { Equality } \\
\text { Variances }\end{array}$} & \multicolumn{7}{|c|}{ t-test for Equality of Means } \\
\hline & & \multirow{3}{*}{$F$} & \multirow{3}{*}{ Sig, } & \multirow{2}{*}{$\mathrm{T}$} & \multirow[b]{2}{*}{ df } & \multirow{2}{*}{$\begin{array}{l}\text { Sig, } \quad(2- \\
\text { tailed })\end{array}$} & \multirow{2}{*}{\begin{tabular}{|l|} 
Mean \\
Differenc \\
\end{tabular}} & \multirow{2}{*}{$\begin{array}{l}\text { Std. Error } \\
\text { Difference }\end{array}$} & \multicolumn{2}{|c|}{$\begin{array}{l}95 \% \text { Confidence Interval of } \\
\text { the Difference }\end{array}$} \\
\hline & & & & & & & & & Lower & Upper \\
\hline & Bqual variances not assumed & & & .751 & 50.806 & .456 & .07937 & .10575 & .29168 & .13295 \\
\hline \multirow[t]{2}{*}{ prep. 6} & Equal rariances assumed & 10.201 & .002 & -1.469 & 53 & .148 & .07407 & .05042 & .17520 & .02705 \\
\hline & Equal tariances not assumed & & & -1.442 & 26.000 & .161 & .07407 & .05136 & .17965 & .03150 \\
\hline \multirow[t]{2}{*}{ prep.? } & Equal variances assumed & 6.458 & .014 & 1.229 & 53 & .224 & .13757 & .11190 & .08687 & .36200 \\
\hline & Bqual variances not assumed & & & 1.235 & 50.980 & .223 & .13757 & .11141 & .08610 & .36124 \\
\hline \multirow[t]{2}{*}{ tot.1 } & Equal variances assumed & 2.588 & .114 & .842 & 53 & .403 & .15608 & .18529 & .52772 & .21555 \\
\hline & Bqual variances not assumed & & & .840 & 50.997 & .405 & .15608 & .18584 & .52918 & .21701 \\
\hline
\end{tabular}

Comparing the control and experimental groups in Tables $3 \mathrm{~A}$ and $3 \mathrm{~B}$, only step 2 in the preparation (Remove protective cap, or clean rubber cap with an antiseptic wipe in circular motion) is statistically significant $(\mathrm{p}=0.007)$.

The results of t-tests between the experimental and control groups regarding the injection of medication is reflected in Table 4. 
Journal of Health, Medicine and Nursing

ISSN 2520-4025 (Online)

Vol.6, Issue 3. No.4, pp 49- 65, 2021

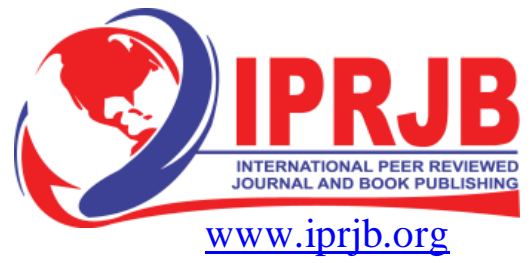

Table 4: Independent T tests between Experimental and Control Groups regarding Injection of Medication

\begin{tabular}{|c|c|c|c|c|c|c|c|c|c|c|}
\hline \multirow[b]{3}{*}{ Variables } & & \multicolumn{2}{|c|}{$\begin{array}{l}\text { Levene's Test for } \\
\text { Equality of Variances }\end{array}$} & \multicolumn{7}{|c|}{ t-test for Equality of Means } \\
\hline & & \multirow[b]{2}{*}{$\mathrm{F}$} & \multirow[b]{2}{*}{ Sig. } & \multirow[b]{2}{*}{$\mathrm{t}$} & \multirow[b]{2}{*}{ dif } & \multirow[b]{2}{*}{ Sig. (2-tailed) } & \multirow{2}{*}{\begin{tabular}{|l} 
Mean \\
Difference
\end{tabular}} & \multirow{2}{*}{$\begin{array}{l}\text { Std. Enror } \\
\text { Difference }\end{array}$} & \multicolumn{2}{|c|}{$\begin{array}{l}\text { 954\% Coufidence Interial of the } \\
\text { Difference }\end{array}$} \\
\hline & & & & & & & & & Lower & Upper \\
\hline \multirow[t]{2}{*}{ iig.1 } & Equal varimces assumed & .572 & .453 & .379 & 53 & .706 & .04630 & .12221 & -29141 & .19882 \\
\hline & Eqqual vaiances not assumed & & & .378 & 52.567 & .707 & .04630 & .12233 & -29170 & .19911 \\
\hline \multirow[t]{2}{*}{ irj.j.2 } & Equd variances assumed & .016 & .901 & .062 & 53 & .950 & .00661 & .10597 & .21917 & .20594 \\
\hline & Eqqual vaiances not assumed & & & .002 & 52858 & .950 & .00661 & .10600 & .21924 & .20001 \\
\hline \multirow[t]{2}{*}{ ixi.j.3 } & Equal varimces assumed & 2.807 & 100 & .929 & 53 & 357 & .12302 & .13242 & -38861 & .14258 \\
\hline & Eqqual vaimces not assumed & & & .928 & 52.479 & .358 & .12302 & .13257 & .38998 & .14295 \\
\hline \multirow[t]{2}{*}{ irj..4 } & Equd variances assumed & .046 & .830 & -1.494 & 53 & .144 & .19974 & .13459 & .46969 & .07022 \\
\hline & Eqqul vaiances not assumed & & & -1.484 & 52899 & .144 & .19974 & .13461 & .46974 & .07027 \\
\hline \multirow[t]{2}{*}{$\operatorname{iij.5}$} & Equal varimces asumed & .098 & .755 & -1.211 & 53 & .231 & -16409 & .13551 & .43589 & .10770 \\
\hline & Eqqul vaiances not assumed & & & -1.211 & 52.951 & .231 & -16409 & .13549 & .43586 & .10768 \\
\hline \multirow[t]{2}{*}{ inj. 6} & Equad varimces assumed & .188 & .667 & .216 & 53 & .830 & .02646 & .12332 & -21888 & .27179 \\
\hline & Equal vaiances not assumed & & & .216 & 52.997 & .830 & .02646 & .1225 & .21875 & .27166 \\
\hline \multirow[t]{2}{*}{ iij.? 7} & Equal variaces assumed & .596 & .44 & .386 & 53 & .701 & .04497 & .11657 & .27878 & .18884 \\
\hline & Eqqual vaimces not assumed & & & .385 & 52440 & .702 & .04497 & .1671 & .27913 & .18918 \\
\hline \multirow[t]{2}{*}{$\operatorname{iig.8} 8$} & Equad variaces assumed & 17.945 & .000 & -1.910 & 53 & .061 & -18783 & .09832 & .38504 & .00937 \\
\hline & Equal vaiances not assumed & & & -1.893 & 41.726 & .065 & -18783 & .09921 & .38809 & .01242 \\
\hline
\end{tabular}


Journal of Health, Medicine and Nursing

ISSN 2520-4025 (Online)

Vol.6, Issue 3. No.4, pp 49- 65, 2021

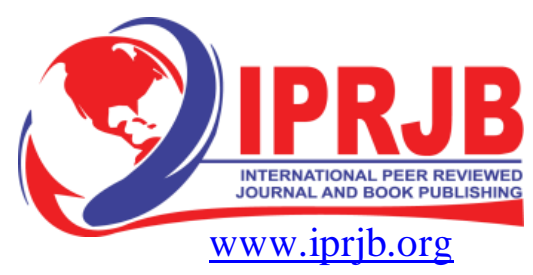

\begin{tabular}{|c|c|c|c|c|c|c|c|c|c|c|}
\hline \multirow[t]{2}{*}{ ing } & Bqu' bines a & 10.0 & 32 & 49 & 5 & 60 & W17 & 1240 & .1865 & 31196 \\
\hline & 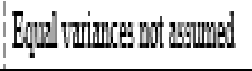 & & & i.i. & 51.66 & 619 & W17 & 1246 & .1102 & 31160 \\
\hline \multirow[t]{2}{*}{ wi. } & 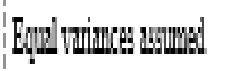 & 11.24 & M. & 161 & 9. & 1010 & .6944 & 3968 & $\cdot 1.4717$ & .140 \\
\hline & 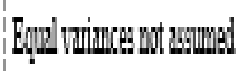 & & & .169 & 47.26 & 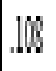 & .6344 & 391 & $-1,4600$ & .1001 \\
\hline \multirow[t]{2}{*}{ watl? } & Eq2 wimen ames & 11.06 & W. & .90 & 3 & 37 & -4.4N & 4166 & $-1,10770$ & .7966 \\
\hline & 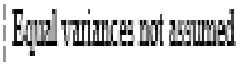 & & & .94 & 47.34 & 30 & -41411 & .4902 & -1.1 .146 & .460 \\
\hline
\end{tabular}

As far as the injection of the medication is concerned as reflected in Table 4, there is no step which is statistically significant.

\section{DISCUSSION}

Findings of this study confirm that of Devi et al. (2019), which showed that while traditional demonstration and the video assisted training were equally effective in enhancing skills, traditional demonstration scored much better than the video-assisted teaching when the posttest skills of the students were compared. Furthermore, the study of Devi et al. (2019) revealed that the routine educational method, i.e., demonstration is more effective in developing skills. It highlighted the reinforcement of academicians in enhancing teaching skills through a blended teaching technique for strengthening memory storage, retrieval, cognition, and learning.

On the other hand, the study of Jang and Kim (2014) negates the findings of this research since it showed that a majority of 411 students from 31 medical schools found OSCE videos effective for their learning of clinical skills and in preparing for OSCE. There was a moderate association between the number of OSCE videos that the students viewed and their self-efficacy and preparedness for OSCE.

In the study of Arsian (2018), the experimental group trained with supported educational videos were found to have higher posttest skill scores in their objective skill clinical examination compared to the control group which was trained with just demonstration method. 
Journal of Health, Medicine and Nursing

ISSN 2520-4025 (Online)

Vol.6, Issue 3. No.4, pp 49- 65, 2021

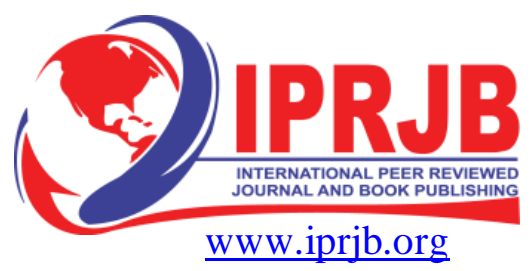

Results of the study of Kelly et al. (2009) which used a developed set of instructional videos for one undergraduate skills-based module showed that students' performance outcomes are unchanged. This lends support to a blended model which is best utilized to complement rather than replace lecture demonstration. The nursing curriculum is changing continuously; however, teaching methods have not kept up with the changing curriculum (Hamilton, 2012).

Various techniques and contemporary methods along with the traditional lecture method are required in teaching different skills (Devi, 2019). When the demonstration method is not available, a suitable substitution could be the video-based education (Doijad, V and Kamble PH, 2013).

As shown by new researchers, video-based instruction has many advantages in comparison with other methods. In the domain of psychomotor learning, however, there is still a dearth of evidence to confirm that video-based instruction is an effective teaching method (Yoo MS, et al., 2010).

\section{Implications}

Findings in our study have implications for improving the practice of using OSCE videos for the teaching and learning of clinical skills (Jang and Kim, 2014). Integration of OSCE videos into teaching is needed for faculty development. Moreover, as educational videos are gaining popularity, there has to be enhanced efforts to integrate interactive tools.

The use of blended learning methods to enhance the acquisition of cognitive knowledge and practical skills is increasingly gaining the attention of educators and academic developers (Forbes et al., 2016).

\section{Conclusion}

In response to the challenges of rapid changes in science and technology and difficulties faced by nurse educators in enhancing the integration of theory and practice, there is a growing trend of incorporating newer strategies in the nursing curriculum. The results of this study indicated that while the traditional teaching strategy and the video assisted training were equally effective in enhancing intramuscular injection skills, traditional teaching scored slightly better than the videoassisted teaching when the OSCE results of the students were compared. 
Journal of Health, Medicine and Nursing

ISSN 2520-4025 (Online)

Vol.6, Issue 3. No.4, pp 49- 65, 2021

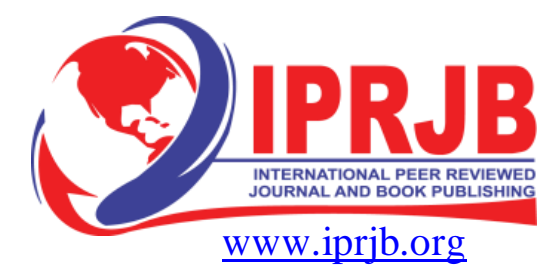

While there is no substitute for clinical demonstration using the checklist, video-assisted teaching can supplement traditionally used bedside demonstration. A combination of teaching strategies can provide a vast opportunity for learning.

This leads to the conclusion that the support of educational videos to conventional teaching methods will enhance the training of nursing skills.

\section{Limitations and Recommendations}

The small number of sample poses a limitation in the generalization of the study findings. Replication of this study, with a larger sample, is recommended. Researches on multiple teaching methods incorporating information technology such as computerized instruction, web-based education, and web-enhanced education can be further conducted.

\section{References}

Agac, E. \& Gunes, U.Y. (2011). Effect on pain of changing the needle prior to administering medicine intramuscularly: a randomized controlled trial. J Adv Nurs. Vol 67. pp. 5638

Agazio, J. \& Buckley, K.M. (2009). An untapped resource. Using You Tube in nursing education. Nurse Educator. 34(1):23-28, doi: 10.1097/01. NNE.0000343403.13234.a2. [PubMed] [Cross $\underline{\text { Ref }] ~[G o o g l e ~ S c h o l a r ~}$

Alawadi, F. (2017). Observational Checklist - As An Instrument to Measure

Arsian, M. (2018). Do Parenteral Medication Administration Skills of Nursing

Baharav, E. (2008). Student's use of video clip technology in clinical education. Top Lang Disord. 28(3). pp. 286-298. doi:10.1097/01.TLD.0000333602.76209 .e7. [Cross Ref]

Bauer, M., Geront, M. \& Huynh, M. (2001). Teaching blood pressure measurement: CD-ROM versus conventional classroom instruction. J Nurs Educ. Vol 40 (3). pp. 138-141. [PubMed] 
Journal of Health, Medicine and Nursing

ISSN 2520-4025 (Online)

Vol.6, Issue 3. No.4, pp 49- 65, 2021

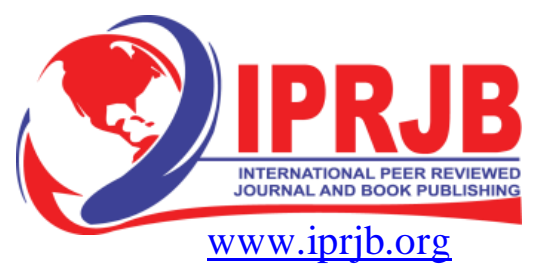

Bennet, M. \& Maniar, M. (2008). Are videoed lectures an effective teaching tool?http://stream.port.ae.uk/papers/Are\%20videoed\%20lectures\%20an\%20effective\%20teachin g\%20tool.pdf

Cofield, J. (2012). An assessment of streaming video in web-based instruction. In: Annual Meeting of the Mid-South Educational Research Association, Biloxi. University of Montevallo, Montevallo. http://www.eric.ed.gov/ERICWebPortal/search/detailmini

Deena, K.A. \& Nashwan, A.A. (2014). An iatrogenic sciatic nerve injuries following gluteal intramuscular injection among children. Int Res J Pharm. Vol 5 (4). pp. 267-70

Devi, B., Khandelwal \& Das Mridula. (2019). Comparison of the Effectiveness of Video-assisted Teaching Program and Traditional Demonstration of Nursing Students Learning Skills of Performing Obstetrical Palpation. Iranian Journal of Nursing and Midwifery Research. Vol 24 (2). pp. 118-123

Doijad V.P. \& Kamble P.H. (2013). A comparative study: learning in experimental physiology with use of liver animals v/s video presentation as learning aids in first MBBS students. Int $J$ Healthcare Biomed Res. Vol 2. pp. 24-9 [Google Scholar]

El-demerdash, S., Mohamed, E., \& Taha. (2015). Adequacy of Intramuscular Injection Among Undergraduate Nursing Students. Journal of International Academic Research For Multidisciplinary. Vol 3 (7). pp. 115-130

Forbes, H., Oprescu, F. I., Downer, T., Philipps, N. M., Mc Tier, L., Lord, B., Barr, N., Alla, K., Bight, P., Dayton, J., Simbag, V. \& Visser I. (2016). Use of videos to support teaching and learning of clinical skills in nursing education: A review. Nurse Education Today. Vol 42. pp 53-56

Forbes, M.O. \& Hickey, M.T. (2008). Podcasting: implementation and evaluation in an undergraduate nursing program. Nurse Educator. Vol 33(5). pp. 224-227. doi: 10.1097/01.NNE.0000334775.98018.e8. [PubMed] [CrossRef] 
Journal of Health, Medicine and Nursing

ISSN 2520-4025 (Online)

Vol.6, Issue 3. No.4, pp 49- 65, 2021

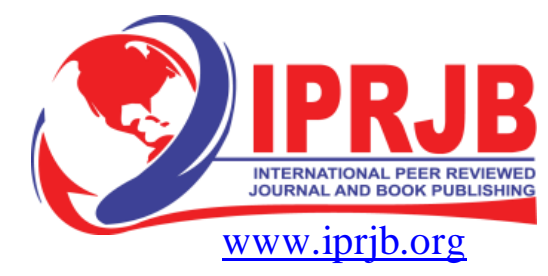

GhamariZare, Z., Purfarzad Z. \& Adib-Hajbaghery M. (2013). Medication Management Skills of Nursing Students: Comparing the Students and Their Instructors' Evaluation in two Universities. Nursing and Midwifery Studies. Vol 2 (1). pp. 139-145

Gulnar, E. \& Ozveren, H. (2016). An Evaluation of the Effectiveness of a Planned Training Program for Nurses on Administering Intramusular Injections into the Ventrogluteal Site. Nursing Education Today. Vol 36. pp. 360-363

Hamilton, N.A., Kieninger, A.N., Woodhouse, J., Freeman, B.D., Murray, D. \& Klingensmith, M.E. (2012). Video review using a reliable evaluation metric improves team function in high-fidelity simulated trauma resuscitation. J Surg Educ. Vol 69. pp. 428-31. [PubMed] [Google Scholar]

Hibbert, E.J., Lambert, T., Carter, J.N., Learoyd, D.I., Twigg, S., Clarke, S. (2013). A randomized controlled pilot trial comparing the impact of access to clinical endocrinology video demonstrations with access to usual revision resources on medical student performance of clinical endocrinology skills. BMC Med. Educ. Vol 13 (1). 135. http://dx.doi.org/10.1186/1472-6920-13$135(1-10)$

Holland, A., Smith, F., McCrossan, G., Adamson, E., Watt, S. \& Penny, K. (2013). Online video in clinical skills education of oral medication administration for undergraduate student nurses: a mixed method, prospective cohort study, Nurse Educ. Today. Vol 33 (6). pp. 663-670. http://dx.dou.org/10.1016/j.nedt.2012.01.006

Intramuscular Injection Administration Skills among Students in the Institute of Nursing, Kuwait. Journal of Education and Practice. 8 (20). pp. 85-92

Jang, Hye Won and Kim, Kyong-Jee. (2014). Use of online video clinical videos for clinical skills training for medical students: benefits and challenges. BMC Medical Education. 14 (56). https://doi.org/10.1186/1472-6920-14-56 Journal of Caring Sciences. 10 (3) 
Journal of Health, Medicine and Nursing

ISSN 2520-4025 (Online)

Vol.6, Issue 3. No.4, pp 49- 65, 2021

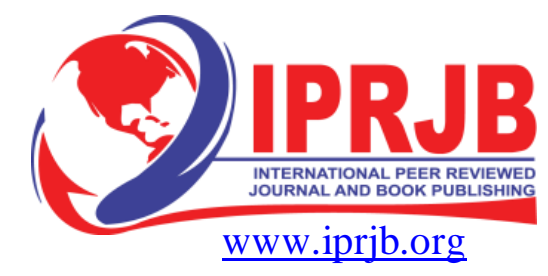

Keelan, J., Pavri-Garcia V., Tomlinson G. \& Wilson K. (2007). You Tube as a source of information on immunization: a content analysis. JAMA. Vol 298 (21). pp. 2482-2484. doi: 10.1001/jama.298:21.2482. [PubMed] [CrossRef] [Google Scholar]

Kelly, M., Lyng, C., Mc Grath, M. \& Cannon, G. (2009). A multi-method study to determine the effectiveness of, and student attitudes to, online instructional videos for teaching clinical nursing skills. Nurse Educ. Today. Vol 29 (3). pp. 292- 300. http://doi.org/10.1016/jnedt.2008.09.004

Potter, P.A. \& Perry, A.G. (2009). Fundamentals of Nursing. 7th Ed. Mosby Inc St. Louis Missouri. pp. 750-754

Rathod, S.S., Motghare, V.M, Padwal, S.L., Deshmukh, V.S., Pore, R.R. \& Deshpande, R. (2013). Study of prescribing practices of injections in outpatients of a rural tertiary care teaching hospital. Int $\mathbf{J}$ Basic Clin Pharmacol. Vol 2. pp. 747-50

Rosen, M. \& Pronovost, P. (2014). Advancing the Use of Checklist for Evaluating Performance in Health Care. Acad Med, Journal of the Association of American Medical Colleges. Vol 89 (7). pp. 1-3

RuLiou, Sh and Yu Cheng, Ch. (2014). Developing and validating the Clinical Competence Questionnaire: A self-assessment instrument for upcoming baccalaureate nursing graduates. Journal of Nursing Education and Practice. 4 (2). www.sciedu.ca/jnep

Sakic, B., Milutinovic, D. \& Simin, D. (2012). An assessment of intramuscular injection among nursing students and nurses in hospital setting: is it evidence-based? South Eastern Health Science Journal. Vol 2 (2). pp. 114-121

Salina, L., Ruffinengo, C., Garrino, L., Massariello, P., Charrier, L., Martin, B., Favale. M.S. \& Dimonte, V. (2012). Effectiveness of an instrument to refresh and reinforce the learning of a nursing technique: a randomized controlled trial. Perspect Med Educ, Vol 1(2). pp. 67-75. doi: 10.1007/s40037-012-0013-4 
Journal of Health, Medicine and Nursing

ISSN 2520-4025 (Online)

Vol.6, Issue 3. No.4, pp 49- 65, 2021

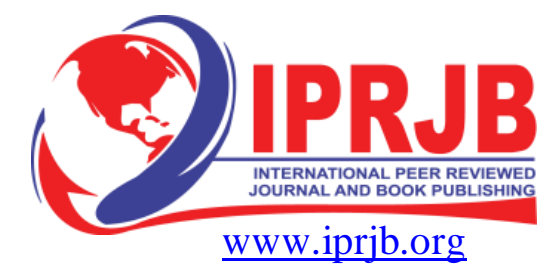

Shill, M.C., Fhad, M.B., Sarker, S., Dev, S., Rufaka, H.K. \& Das, A.K. (2011). Injection practices at primary healthcare units in Bangladesh: Experience at six Upazilla health complexes. Australas Med J. 4 (1), 26-42.

Srividya, B., Nagabushan, H. \& Drupad, H. (2015). Assessment of Knowledge among Health care providers regarding intramuscular injection administration. Asian Journal of Pharmaceutical and Clinical Research. Vol 8 (1). pp. 220-222

Students Increase with Educational Videos Materials? Scandinavian

Takeda, N., Takeuchi, I. \& Haruna, M. (2007). Assessment of learning activities using streaming video for laboratory practice education: aiming for development of e-learning system that promote selflearning. Yakugaku Zasshi J Pharm Soc Jpn. Vol 127(12). pp. 2097-2103. doi: 10.1248/yakushi.127.2097. [PubMed] [CrossRef]

Thornhill, S., Arsenio, M. \& Young C. (2002). Video streaming a guide for educational development. Manchester: The JISC Click and Go Video, ISD, UMIST, Manchester

Todd, K.H., Braslow, A, Brennan, R.T., et al. Randomized, controlled trial of video self-instruction versus traditional CPR training. (1998). Ann Emerg Med. Vol 31(3). pp. 364-369. doi: 10.1016/SO1960644(98)70348-8. [PubMed] [CrossRef]

Topal, F.E. \& Yildirim, B. (2014). The assessment of distances of intramuscular injection location from some landmarks in the students of Mugla School of Health Sciencs. Cumhuriyet Med J. Vol 36. pp. 206-14

WHO - Guiding principles to ensure injection device security- BCT/03.12. Available from: http://www.who.inr/injection_safety/WHOGuidPrinciplesnjEquipFinal.pdf.

Yoo, M.S., Yoo, I.Y. \& Lee, H. (2010). Nursing students' self-evaluation using a video recording of Foley catheterization: effects on students' competence, communication skills, and learning motivation. J Nurs Edu. Vol 49. pp. 40 